\title{
Grassroots Capacity Building for REDD+: Lessons from Nepal
} Harisharan Luintel*, Chandra Shekbar Silori**, Simone Frick ** and Bishnu Hari Poudyal****

*The School of Environment, Portland State University, USA

**Grassroots Capacity Building for REDD + in Asia, RECOFTC, Thailand

$* *$ Grassroots Capacity Building for REDD+ in Asia, RECOFTC - Nepal

Corresponding author: hluintel@gmail.com

\begin{abstract}
Meaningful engagement and effective participation of grassroots stakeholders and forest managing communities in national policy formulation and local institutional processes for forest management have implications for the future global climate regime and poverty reduction among forestdependent poor. In this context, the institutional and technical capacity of grassroots stakeholders is critical in ensuring effective and successful implementation of Reducing Emissions from Deforestation and Forest Degradation, including Conservation and Sustainable Management of Forests and Enhancement of Forest Carbon Stocks (REDD+). Capacity building for grassroots stakeholders is particularly crucial as REDD+ has to be implemented in a complex local environment shaped by multiple land use systems, sharply divided politics, conflicting policies, different levels of forest dependencies, complex social relations, unclear governance and tenure structures and differential climate impacts. It has been learned from the grassroots capacity building programme that there is a need of partnership and collaboration between grassroots stakeholders to build capacity for fighting against climate change at local level. However, there is no 'one size fits all' formula for capacity building, partnership and collaboration. Multi-pronged and multi-scale capacity strengthening strategies that draw on the strengths of various learning methods and address the unique needs of targeted stakeholders would be effective. These would/ should always be target-driven, addressing the specific needs and conditions of stakeholders, and reflecting their sustainable development strategies, priorities and initiatives. There is still a need to re-orient and strengthen the capacity of the key stakeholders of REDD+ in Nepal so that they can better analyse and understand their own carbon forestry conditions and develop strategies to get more benefits from the REDD+ scheme.
\end{abstract}

Key words: REDD+, capacity building, stakeholders, institutions, community forestry

\section{INTRODUCTION}

Reducing Emissions from Deforestation and Forest Degradation, including Conservation and Sustainable Management of Forests and Enhancement of Forest Carbon Stocks, collectively known as REDD+, has been proposed as a novel collaborative action between developed and developing countries as part of a climate change mitigation strategy under the United Nations Framework Convention on Climate Change (UNFCCC). It creates an opportunity for financial value for the carbon stored in forests of tropical developing countries, offering incentives for, forest managers/owners for their efforts in reducing greenhouse gas (GHG) emissions from forest lands and increasing absorption of atmospheric carbon by managing/conserving forest sustainably.
Meaningful engagement and effective participation of developing countries, particularly those of grassroots stakeholders and forest managing communities in international climate negotiations, national policy formulation and local institutional processes have implications for the future global climate regime, national forest management strategy, local forest ecosystem condition and poverty reduction among forest-dependent poor. As the concept of REDD+ grows, almost all conventional forestry stakeholders have become more interested to know about the applications and implications of REDD+, while a number of new forestry stakeholders are also emerging at different levels. These have triggered all stakeholders re-thinking primary objectives of 
forest management and therefore have caused re-configuration of power relationship among and between them as they prioritize forest management differently for provisioning, environmental, cultural and supporting services. Compounding with their different priorities, the global and local contexts also indicated the need for a change in the locus and the direction of environmental justice studies (Pellow and Brulle 2005). Consequently, both conventional and newly emerging forestry stakeholders need capacity building services in terms of reorientation and political know-how, knowledge and tools, public support and scientific expertise on REDD+. The institutional and technical capacity of REDD+ stakeholders at the national and grassroots levels have been critical in ensuring effective and successful implementation of REDD+. Capacity building for grassroots stakeholders is particularly crucial as REDD+ has to be implemented in a complex local environment, shaped by multiple land use systems, sharply divided politics, conflicting policies, different levels of forest dependencies of communities, complex social relations, unclear governance and tenure structures, and differential climate impacts.

By taking a case of Nepal, this article primarily draws on the REDD+ capacity building activities implemented from 2009 to date in a developing country. The paper highlights the gap in the capacity of key stakeholders of REDD+ in Nepal. Particularly, stakeholders need re-orientation and capacity building services for better analysis of carbon forestry conditions so as to develop strategies to get more benefits from the REDD+ scheme. In addition to the national level, a need of partnership and collaboration between grassroots stakeholders have been identified as a pre-requisite for capacity building for fighting against climate change at local level. Multi-pronged and multiscale approaches that draw on the strengths of various learning methods and addresses the unique needs of targeted stakeholders would be an effective strategy for sustainable capacity building system in place.

The article is organized as follows. While the section one introduces the paper, section two briefly highlights REDD+ debate and the context for REDD+ capacity in Nepal. Similarly, section three specifically dwells on how a donorfunded project conducted a set of capacity building interventions. Section four discusses some critical lessons that show both opportunities and challenges of REDD+ capacity building programme in a developing country. As conclusion, the final section of the paper indicates some important insights, that have implications for the future programme of REDD + in Nepal, gained so far from the project experience.

\section{REDD+ DEBATE AND CAPACITY BUILDING CONTEXT IN NEPAL}

\section{Debate around REDD+}

In 2008, when not so extensive on-the-ground REDD+ experiences were available, REDD+ was seen as a cheap, quick, win-win and significant way to reduce carbon emissions (Angelsen 2008). So far, REDD+ is considered as a mechanism of increased investment in forest management that can bring myriad of opportunities, including achieving critical developmental goals (Economist 2010a), enhancing forest governance and bolstering global conservation efforts (Wollenberg and Springate-Baginski 2010), and reducing carbon emissions and deforestation in tropical countries (Toni 2011). Many people believe that REDD+ not only promotes investment in low carbon paths to sustainable development but also generates funds to fight against persistent problems of deforestation, biodiversity loss and poverty in developing countries. Therefore, REDD + has been receiving greater attention in climate negotiations, and a range of policies and 
institutional arrangements in terms of design and architecture are now being discussed in making it practical and effective.

Nevertheless, there are evidence, and articulations that REDD+ poses many challenges in participating developing countries. This is particularly true as the forest management and land use planning, effective governance, secure tenure and clear property rights, which are yet to be defined clearly, are prerequisites for the success of REDD+ (Cotula and Mayers 2009; Pettenella and Brotto 2012). REDD+ as an influential financial tool can change the landscape of forest governance and exacerbate the persistent efforts of governments and corporations to exert increasing centralized control over forests (Economist 2010b; Lovera 2009; Phelps et al. 2010; Khatri 2012), and negatively affect the poor communities expected to benefit from REDD+ (Ratsimbazafy et al. 2011). Moreover, it demands different sets of social, environmental and technical standards at international level that should be fulfilled by the participating country or the REDD+ project, which may need competency in advanced science-based technical knowledge and skills. In the context of community forestry (CF), the communities' time-tested and locally relevant traditional knowledge may perhaps be limited in meeting such international standards technically. Therefore, many scholars, policymakers, practitioners and communities have raised concerns on whether the forest managing communities can meet the standards and get benefits from REDD+. To make this issue more understandable and approachable, communication between policymakers at national/ international levels and local forest managing communities may need to be strengthened. Capacity building approach to grassroots and national levels are therefore considered as one of the important initiatives in this regard.

\section{Capacity Building Context for REDD+ in Nepal}

The prospect of REDD+ in Nepal depends mainly on the (i) extent and condition of forest cover, forest carbon stock, historical trends of deforestation and forest degradation, and forest management practices; (ii) policy framework, forest governance, tenure and equity; and (iii) REDD+ initiatives and the mandate, commitment and competency of both existing and evolving stakeholders in REDD+. Therefore, understanding these contexts properly and designing appropriate capacity building activities are crucial.

Nepal's contribution to the annual GHG emission is 39,265 gigagram $(\mathrm{Gg})$, which constitutes $0.025 \%$ of global emissions (MoEST 2004). Since Nepal primarily has a subsistence agricultural economy and poorly developed industrial infrastructure, land use and land use change including forests constitute major part of GHG emissions. It has been evident that the deforestation was at an annual rate of 0.5 percent during the period 1978/79-1994 (DFRS 1999). Recent studies in 20 deforestation prone southern plain districts suggest that the forest cover has decreased only at an annual rate of 0.06 percent during the period 1990/91-2000/ 01 (DoF 2004). A large part of this reduction in deforestation rate perhaps could be attributed to the CF programme. The total carbon stock in Nepal's 5.8 million hectare (ha) forest is nearly 900 million tons ( 152.83 tons per ha) from 1990 to 2005 , which has slightly fluctuated over time (FAO 2006, cited in Oli and Shrestha 2009). It has recently been observed from a study in 104 community forest user groups (CFUGs) in three sub-watersheds in Nepal that nearly 2.67 ton/ha $(1.75 \%)$ per hectare carbon has increased in Community Forests from 2010 to 2011 due to implementation of REDD+ pilot project (ICIMOD et al. 2011). However, there are a 
range of issues associated with ecological aspects of forest management in Nepal, which includes existence of passive management of forest (Yadav et al. 2003), haphazard and over-harvesting of non-timber forest products (NTFPs) and medicinal plants (Luintel 2002; Luintel et al. 2004), lack of effective technical knowledge among users, and prevalence of ineffective support system of state forest agencies (Paudel et al. 2012), and inadequate investment to forest management. Moreover, despite recognizing the existence of challenges in integrating biodiversity concerns in the REDD+ scheme (Gardner et al. 2012), adequate discussions in this regard have not been carried out in Nepal.

Through the introduction of the Master Plan of Forestry Sector (MPFS) 1989 and Forest Act 1993, Government of Nepal (GoN) transferred forest management responsibility and forest product use authority to CFUGs. In fact, the Plan and Act legitimized, formalized and revitalized the local and indigenous forest management practices across the country. The Act recognized the CFUGs as self-governing, independent, autonomous and corporate institutions so that they could acquire, possess, transfer, or otherwise manage movable or immovable property (HMG/MoLJ 1993: Article 43). The use rights usually include basic forest products such as fodder, fuelwood and NTFPs but exclude environmental services, including carbon sequestration, water yield and biodiversity conservation. Therefore, use of these services has generally been restricted or regulated through several stringent conditions. Since overall property rights of forest ecosystem goods and services and forestland remain with community and government (biomass and tangible forest products with communities, forestland with government, and intangible ecosystem services not specified so far), greater complexities and ambiguities prevail in the use of CF resources. Understanding tenure security in Nepal's CF has been a daunting task (Luintel and Chhetri 2008). This seems to be further aggravated by changing market structure for ecosystem services within the framework of REDD+. Similarly, despite civil societies' facilitating equity promotion in CF (Luintel 2006), there are elite domination and inequity (Neupane 2003; Malla et al. 2003), participatory exclusion (Agrawal 2001) and token participation of women (Luintel and Timsina 2008). However, CF offers prospects for strengthening local institutions and democratic resource governance (Pokharel 2005; Pokharel et al. 2007), empowering women (Chhetri et al. 2008) and the marginalized, supporting social harmony and peace-building process during the post-conflict period (B.K. et al. 2009; Luintel et al. 2009), and community and local development (Chapagain and Banjade 2009), which could be capitalized on to institutionalize REDD+.

To prepare the country for REDD+, the GoN has not only created the REDD Forestry and Climate Change Cell (REDD Cell) under the Ministry of Forests and Soil Conservation but also has been participating in the Forest Carbon Partnership Facility (FCPF) programme of the World Bank and also UN-REDD. It has also formed a national REDD+ Working Group with representation from the government, experts, donors and civil society to forge wider collaboration for generating support to address drivers of deforestation and forest degradation. After the preparation of the Readiness Preparation Proposal (R-PP), GoN is now developing policy and institutional infrastructure for implementation of REDD+ in collaboration with different international/ national non-governmental organizations (I/ NGOs), which have different but inter-related institutional mandates, commitments, focus and competencies (Paudel et al. 2010). So far, a range of awareness raising and capacity building activities, participatory action research and policy analysis have been carried out. Gradually,

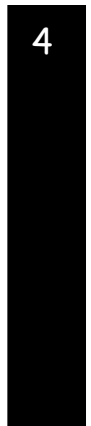


discussions on the possibilities and implications of REDD+ are being institutionalized in the forestry sector. However, at times, the whole REDD + initiatives seem to be driven by donorfunded projects and there is still a need to bridge the gap between international REDD+ policy and expectations of grassroots stakeholders. Capacitating and allowing grassroots stakeholders to voice their concerns and expectations at national- and internationallevel policy processes seem to be an urgent and logical need.

So far, it has been noticed that community networks, including the Federation of Community Forest Users Nepal (FECOFUN), Himalayan Grassroots Women's Natural Resource Management Association (HIMAWANTI) and the Nepal Federation of Indigenous Nationalities (NEFIN) have been actively engaged in articulating and advocating the recognition and inclusion of local communities' and indigenous peoples' rights in the REDD+ scheme. Similarly, other professional organizations such as ForestAction Nepal, International Centre for Integrated Mountain Development (ICIMOD), Asia Network for Sustainable Agriculture and Bioresources (ANSAB), World Wide Fund for Nature (WWF), among others are working in the field of REDD+. However, techno-centric discussions have primarily dominated the overall REDD+ initiatives in Nepal, as the language and issues on REDD+ is alien, abstract and full of technical jargon. This has lessened the accessibility of most local forest-dependent people to the REDD+ initiatives. Also, there are limited exploratory studies to show how emerging REDD+ mechanisms can help address impacts, problems and issues of climate change and rural poverty at local level. Different pertinent questions regarding REDD+ have been raised and remain unanswered so far. Some of these questions include, (i) How do REDD+ initiatives affect existing CF in Nepal?; (ii) Is CF eligible to generate benefits from REDD+?; (iii) Can REDD+ benefits support in reducing rural poverty?; (iv) How will community rights to forests be affected by REDD+?; and (v) Does REDD + effectively address the drivers of deforestation and forest degradation? Understanding the implications of REDD + and seeking answers to these questions are vital in the Nepalese context, which perhaps can be of interest elsewhere in the context of participatory forestry. To answer these questions and make REDD+ effective, challenges exist at political, policy, institutional, technical and informational level.

\section{CASE: REDD+ CAPACITY BUILDING PROJECT}

In Nepal, RECOFTC - The Center for People and Forests, has been implementing the Grassroots Capacity Building for REDD+ project since November 2009 with the financial assistance of the Norwegian Agency for Development Cooperation (NORAD) and in partnership with FECOFUN and other organizations. The main goal of the project is to strengthen capacity of the grassroots forest stakeholders for successful implementation of REDD+ and, therefore, contribute to local socio-economic development. To achieve the goal, the project identified and addressed key knowledge gaps among grassroot stakeholders so that they are able to participate actively in the policy and planning process of REDD ${ }^{1}$. The major focus of the project includes development and timely revision of REDD+ awareness and training materials, organizing awareness raising and capacity building activities on the basic concept of REDD+, as well as documentation and sharing of REDD+ issues. The details of the project intervention are

${ }^{1}$ Grassroots Capacity Building Programme for REDD in the Asia-Pacific Region, Project Proposal for Norway Government's Climate and Forest Initiative Funding Scheme - 2009, RECOFTC 2009. 
briefly presented in the following six subsections.

\section{Understanding the Context and the Issues}

The project started with an effort to understand the context and capacity of forestry stakeholders. Specifically, through an extensive consultative process, a capacity building need assessment (CBNA) was carried out on the basis of competency standards developed to gauge the level of fundamental knowledge and understanding of REDD+ among national, subnational and grassroots stakeholders. Five different types of institutions, including government agencies, federations and networks, projects, NGOs and media having different competencies, strategies, mandates, commitments and focuses, were identified as potential stakeholders for REDD+. The grassroots stakeholders generally lack conceptual understanding of REDD+ despite their demonstrated efforts in revitalizing degraded forests. Even service providers at meso and national level were not aware of REDD+, including its political, social, institutional, economic, ecological and methodological aspects.

The project adopted a multi-pronged and multiscale strategy for developing a comprehensive capacity building package that draws on the strengths of various learning methods and addresses the unique needs of targeted stakeholders for national to local level. The package provided a space for collaboration and partnership at different levels. A cascade approach to deliver training was identified as the main strategy for capacity building, while other non-training strategies such as networking, seminars, issue-based public discussions, scientific research, publication of information, education and communication (IEC) materials, media mobilization, mass gathering and consultative meetings were also adopted. Similarly, institutional, technical and methodological skills at national and subnational level and general awareness of the rights of communities at grassroots level were identified as specific needs for capacity building purpose.

\section{Planning Project Activities}

A series of meetings with project partners and collaborators were organized, leading to a detailed implementation and monitoring plan of the project. Project sites were identified on the basis of geographical coverage, deforestation trend, socio-economic conditions of forest managing communities and the interest of partners to collaborate. Partnerships and collaborations with different organizations were identified as a key strategy for the project implementation. Most of the activities were planned in the form of cascade training and awareness raising events at different levels. Since there was interest from a wider level of communities, strategies were developed to bring and engage participants from beyond conventional forestry stakeholders during the trainings. To collect feedback from resource persons, facilitators, participants and participating institutions for identifying effectiveness of input, output and outcomes of training, a comprehensive monitoring plan was prepared.

\section{Preparation of IEC Materials}

A range of IEC materials were prepared, reviewed, tested and published in partnership and collaboration with a wide range of institutions, including REDD Cell, FECOFUN, HIMAWANTI, NEFIN, ForestAction Nepal, ICIMOD and ANSAB. The partnership and collaboration among institutions created synergy and ensured goodquality IEC materials. Particularly, two training manuals-one for a five-day national and subnational-level training and another for a twoday community-level training-information 
fliers, booklets and posters were published at the initial stage. Most of the issues identified during the CBNA process and in different discussion forums were covered at different levels in these materials. The training manual focused on sensitization and general awareness of informational, institutional, social and economic aspects of REDD+. Some of the issues covered in the training manuals were the concept and context of climate change, the role of forests in climate change mitigation and adaptation, the concept and requirements for REDD+, Nepal's engagement in REDD+, opportunities and challenges of REDD+, forest management regimes of Nepal, causes of deforestation and forest degradation, and implications of REDD+ for forest conservation and livelihoods.

\section{Awareness Raising Activities}

REDD+ being an abstract and novel concept, many stakeholders were interested to know about the subject, and, therefore, general awareness raising activities became a priority. By mobilizing a variety of existing communication channels, a wide range of audience were targeted. Write-shops and training events were organized to capacitate journalists and media workers at national and regional levels, which were followed by broadcasting a number of radio programmes and publication of fact-based articles on REDD+ and climate change in print media. Similarly, to respect local initiatives and make the programme more effective at local level, street plays were performed; and cultural programmes were organized by mobilizing local organizations with new sets of information.

\section{Capacity Building Activities}

Capacity building activities were primarily based on training at national (3-5 days), sub-national (3-5 days) and local (1 day) level. A cascade approach was strictly followed to deliver training at district and community level. Approximately
20 thousand participants, including forest managing communities (men, women, marginalized and indigenous peoples), government forestry staff, NGO activists, freelance consultants, political leaders, network members, project staff, academicians, social workers, journalists and entrepreneurs participated in the training. To bring synergy, each event was organized in collaboration with local partners and facilitated by a number of local facilitators using participatory methodologies. Hands-on support and coaching constituted an important part of capacity building for district and local level facilitators.

\section{Issue Based Discussions, Case Documentation and Lessons Sharing}

Different REDD+ related issues were identified during interactions in the training. Some of those issues were brought to the national and sub-national-level stakeholders' attention for further discussion, clarification and action. Among those issues, conflicts, internal group governance and forest product utilization were selected for research, documentation and wider sharing. The findings and the conclusions derived from the discussions and/or research have been incorporated in the revision of IEC materials and training. The overall lessons of the project are now being documented and shared with wider audiences such as policymakers, development professionals and academicians within the country and beyond.

\section{ISSUES AND LESSONS OF CAPACITY BUILDING INTERVENTIONS}

\section{Forging Partnership and Collaboration: A Daunting Task}

With an aim to create ownership and increase participation, capacity building interventions were implemented in partnership and collaboration with different organizations at all levels. These have been crucial for legitimacy, 
credibility, effectiveness and efficiency of interventions, which resulted in greater absorption of delivered message by the target groups. These also provided an environment conducive to diversify the participation in the programme, facilitate communication and share responsibilities between different stakeholders, all of which are crucial for managing local forests and controlling deforestation and forest degradation. The partnerships and collaborations, by generating wiser decisions, producing more durable decisions and promoting desired changes, are expected to result in effective forest management and better environmental quality. Moreover, these reinforce democratic values and can improve the health of communities by building social capital and fostering collective ownership of problems and resources. Particularly at the national level, relatively expected outcomes were achieved. This is partly attributed to the careful planning and engagement with more professional organizations having adequate resources, knowledge and experience of partnership and collaboration.

Despite overall positive experience in partnerships and collaborations, some challenges and issues were observed at district and community levels. This is perhaps because of the fact that the organizational culture of collaboration and partnership for a certain project is yet to sink down to local level. Grassroots organizations perhaps were not able to properly identify their own strengths at the beginning of the project and, therefore, missed opportunities to fully capitalize on those during project implementation. Defining accountability structure, sharing resources, ensuring synergy and planning greater learning remained challenging at the beginning. The organizations that had greater resources, administrative control, and skills and knowledge of forestry tend to have greater power and control in partnership and, therefore, at times, were not welcomed by other collaborators, which limited collaboration to a mere formality. As partnerships and collaborations were forged hastily without adequate planning and understanding the expectations from partnership, it took longer time and more efforts in creating a shared vision and building trust among collaborators, resulting in trade-off in intended outcomes.

\section{Developing Facilitators and IEC Materials: Way to Sustain Capacity Building Interventions}

Capacity building interventions were planned considering institutionalization and sustainability, and therefore, development of REDD + facilitators and IEC materials were the primary focus. In this regard, selecting and equipping facilitators with appropriate and adequate knowledge, skills and motivation have been crucial. Both institutional background and individual interest and commitment were considered equally important while selecting participants. Despite difficulties associated with selecting appropriate participants, institutionally and culturally suitable, practical and informal ways, such as participatory development of criteria in advance, consultation with the concerned institutions/individuals have been proved useful. It has also been noticed that socio-cultural, personal and professional images of facilitators have implications for the uptake of training delivery at the local level. This is particularly important when abstract and novel concepts like REDD+ are under consideration.

As REDD+ is a new, abstract and emerging concept, production of evidence-based, concise and relevant IEC materials in local language has been crucial for efficiently informing local participants. Many terminologies and concepts used in REDD+ and climate change are still difficult to translate into local languages, which hinders the learning efficiency. The format of 
the material (text, diagram, picture, audio, etc.) has also been equally important to make the complex message simple and easy to understand. The pictorial materials that logically present the message have been effective in making capacity building interventions successful. Pooling different expertise in developing, reviewing and testing materials added great value. Welldeveloped materials in durable form could be referenced in the future as well. It has been noticed that a good mix of concepts and examples from international, national and local levels are effective in communicating with people at different levels.

\section{Implementing Capacity Building Interventions: Way to Reinforce Learning}

Capacity building interventions were broadly limited to sensitization and training, focusing on imparting knowledge at individual level. Customized and two-way communication that links concepts and evidence between training facilitators and participants has had a crucial role for making these interventions effective. Therefore, greater flexibility was allowed to facilitators to communicate adequately and appropriately. A combination of local and national facilitators has been effective in synergizing learning as they complement each other by bringing local perspectives and examples, and clarifying conceptual issues respectively. Similarly, local facilitators seemed to value an endogenous, incremental and continuous process of institutionalization and learning, while external facilitators tend to bring novel perspectives and inject ideas for breakthrough in institutional and learning processes. However, care should be taken that these perspectives do not conflict with each other and retard the overall learning process.

It has also been realized that series of linked interventions, in a package, at institutional and system levels and also complemented by mass communication would be more effective than snap-shot events to institutionalize capacity building. The strategies followed by facilitators to deal with conflicting issues such as allowing more discussions from different perspectives have had greater bearing on the effectiveness of training. While some facilitators tried to avoid confusing and conflicting issues, many others brought such issues to the centre of discussion and made them more lively and productive.

\section{Carrying Out Awareness Raising Activities: Reaching Out to Many Stakeholders}

With an aim to reach a wider audience with the message on climate change and REDD+, a range of activities such as mobilizing journalists through writing feature articles, broadcasting radio and television programmes, performing cultural programmes and organizing street plays were carried out. Mobilizing mass communication channels for raising awareness has proven to be important to generate support in capacity building activities and local environmental and forestry initiatives.

Since most of the journalists are engaged and interested in political, urban and semi-urban issues, with an aim to gain better professional position, name, fame and resources, it has been challenging to find suitable persons who are interested in environmental, forestry and rural issues. Also, the gap in relationship between local collaborators and journalists remained a challenge to mobilize media effectively. The disciplinary and sectoral knowledge and focus of forestry stakeholders and media persons also did not match, which limited building of professional relationships. For example, media persons might be interested to cover bad news as they travel faster than analytical articles advocating communities' rights on natural resources. However, collaborators like FECOFUN and HIMAWANTI are interested to convey success stories of inspiring nature and 
community rights, which demands more energy, efforts and passion. Also, most media have oneway communication channel and are limited in creating impact. However, a series of interactive programmes in Radio that incorporate voices and issues of local people were effective in delivering the message. Similarly, broadcasting time and method also mattered a lot for the effectiveness of the message. For instance, artistic presentation such as street drama and cultural programmes was easily taken up and retained for longer.

\section{Maintaining Diversity: Way to Bring Synergy}

Efforts were put to achieve synergy diversifying capacity building interventions, participation, facilitation, collaboration and partnership. These diversities brought both opportunities and challenges. Different non-conventional forestry stakeholders such as media and the private sector are now interested to contribute to local forest management, climate change adaptation and environmental improvement. The conventional forestry stakeholders are now interested to set up multi-stakeholders forums for collectively addressing deforestation and forest degradation issues by bringing creative and novel ideas from all collaborators.

Diversity in interest, competency and perspective made stakeholders unique and therefore brought conflicts as well. In such cases, synergizing through partnership and collaboration have been challenged. More efforts, transaction costs and energy were needed for synergistic collaboration in such situation. At times, diversity became a source of discrimination and exploitative power relations between stakeholders and, therefore, the question of fairness emerged. The differences in understanding level and learning capacity among partners and collaborators have had implications for making capacity building effective.

\section{Conducting Monitoring: Making Interventions Effective}

Proper monitoring has been essential in ensuring the effectiveness of capacity building interventions in terms of learning and behavioural change. The project planned and conducted different levels of monitoring including taking baseline of knowledge, and input for, output of and outcome of capacity building interventions. At times, it has been noticed from the on-going monitoring that some of the capacity building interventions had disempowering effects on the participants. For instance it occured while the forest managing communities realized that the international standards for REDD+ are complex and difficultto-understand. Such confusions generally occurred when abstract and novel concepts were discussed without local examples. However, such effects were short-lived as the facilitators carefully dealt with them. Monitoring has also been found to be important in creating an environment conducive to bringing different views from participants and maintaining healthy discussions and knowledge sharing.

\section{CONCLUSION}

While the capacity building interventions were primarily focused on strengthening knowledge of existing forest governance and management in view of climate change and REDD+ through training, coaching and hands-on support, awareness raising activities increased political know-how and generated public support for better forest management so as to contribute to climate change mitigation and adaptation. Capacity building interventions have been generally promoted and institutionalized as a collaborative learning process among a wide range of stakeholders. While partnership and collaboration boosted local institutions' competency in forest management, REDD+ and climate change by bringing their ideas, competencies and resources together, these have 
been instrumental for legitimacy, credibility, effectiveness, and efficiency (through synergy) of the intervention. However, there is no 'one size fits all' formula for capacity building interventions including partnership and collaboration; they could and should always be target-driven, addressing specific needs and conditions of stakeholders and reflecting their sustainable development strategies, priorities and initiatives. For REDD+ grassroots stakeholders, a multi-pronged and multi-scale capacity strengthening strategy that draws on the strengths of various learning methods and addresses unique needs of targeted stakeholders would be effective. Development of facilitators, advocates and IEC materials are proved to be effective to expand and sustain the main ideas of capacity building interventions beyond the temporal and spatial limits of the project. Similarly, monitoring has also been crucial to focus the limited resources in the intended interventions, timely correction of the unintended effects and maximize the learning.

The clearer the linkages between climate change and REDD+ with forest management, community development and local livelihoods of the grassroots stakeholders, the better would be the support for them in preparing climatefriendly development packages. The crucial elements for this - capacity building, partnership and collaboration - can be fostered through both promoting local initiatives and mobilizing externally sponsored development resources. However, this may take some time, efforts and cost to institutionalize due to existence of unequal power relations between grassroots stakeholders, which are shaped by not only traditional socio-cultural values but also differential access to knowledge, skills and resources guided by modern institutional set up.

The project helped local people to increase their level of understanding on climate change, REDD+ and local forest management in an integrated way. However, a key challenge still remains on how and through which ways stakeholders might have access to REDD+ resources and begin to critically judge the prospects of REDD+ and voice their concerns at different levels of policy processes. Still, key champions of REDD+, including researchers, consultants, negotiators, rights activists and real forest stewards tend to put more efforts on exploring ideas on how to comply with emerging options as if they were final, rather than exploring and advocating their own expectations in the context of evolution of REDD+ architecture and policy at the international level. Hence, there is still a need to re-orient and strengthen the capacity of key stakeholders of REDD+ in Nepal so that they can better analyze and understand their own carbon forestry conditions and develop strategies to get more benefits from the REDD+ scheme.

\section{REFERENCES}

Agrawal, B. 2001. Participatory Exclusions, Community Forestry and Gender: An Analysis for South Asia and a Conceptual Framework. World Development, 29(10): 16231648.

Angelsen, A. (Ed). 2008. Moving Ahead with REDD: Issues, Options and Implications. CIFOR, Bogor, Indonesia.

BK, N., Shrestha, R.K., Acharya, S.G. and Ansari, A.S. 2009. Maoist Conflict, Community Forestry and Livelihoods: Pro-poor Innovations in Forest Management in Nepal. Journal of Forest and Livelihood, 8(2): 93-100.

Chapagain N and Banjade MR. 2009. Community Forestry and Local Development: Experiences from the Koshi Hills of Nepal. Journal of Forest and Livelihood, 8(2): 78-92.

Chhetri, R.B., Timsina, N.P., Luintel, H., Regmi, R., Bhattarai, B. and Magar, R.A. 2008. Decentralization and Promotion of Women's Rights in Nepal: Exploring Constraints, Opportunities and Intervention Avenues. ForestAction Nepal and International Development and Research Centre.

Cotula, L. and Mayers, J. 2009. Tenure in REDD: Start-Point or Afterthought? Natural Resource Issues No. 15. London: International Institute for Environment and Development.

DFRS. 1999. Forest Resources of Nepal (1987-1998). Kathmandu: Department of Forest Research and Survey, Ministry of Forests and Soil Conservation.

DoF. 2004. Forest Cover Change Analysis of the Terai Districts (1990/91-2000/01). Kathmandu: Department of Forest, Ministry of Forests and Soil Conservation. 
Economist. 2010a. Better REDD than Dead. The Economist, 25 September 2010

Economist. 2010b. Not a Small Problem: Will REDD Trample on the Rights of Traditional Forest Folk? The Economist, 25 September 2010.

FAO. 2006. Global Forest Resource Assessment 2005. Rome: Food and Agriculture Organization of the United Nations.

Gardner, T.A., Burgess, N.D., Aguilar-Amuchastegui, N., Barlow, J., Berenguer, E., Clements, T., Danielsen, F., Ferreira, J., Foden, W., Kapos, V., Khan, S.M., Leesm, A.C., Parry, L., Roman-Cuesta, R.M., Schmitt, C.B., Strange, N., Theilade, I. and Vieiram, I.C.G. 2012. A Framework for Integrating Biodiversity Concerns into National REDD+ Programme. Biological Conservation, 154: 61-71.

HMGN/MoLJ. 1993. Forest Act 1993. Kathmandu: His Majesty Government of Nepal/Ministry of Law and Justice.

ICIMOD, ANSAB and FECOFUN. 2011. A Monitoring Report on Forest Carbon Stocks Changes in REDD Project sites. Kathmandu: International Center for Integrated Mountain Development, Asia Network for Sustainable Agriculture and Bioresources and Federation of Community Forest Users Nepal.

Khatri, D. 2012. Is REDD+ Redefining Forest Governance in Nepal? Journal of Forest and Livelihoods, 10(1): 74-87.

Lovera, S. 2009. REDD Realities in Contours of Climate Justice: Ideas for Shaping New Climate and Energy Policy. In: U. Brand, N. Bullard, E. Lander and T. Mueller (Eds.). Critical Currents, 6: 46-53. Uppsala: Dag Hammarskjöld Foundation.

Luintel, H. 2002. Issues and Options of Sustainable Management of Himalayan Medicinal Herbs. Journal of Forest and Livelihood, 2(1): 53-55.

Luintel, H. and Chhetri, R.B. 2008. Understanding Tenure Security in Community Forestry. Journal of Forest and Livelihood, 7(1): 1-5.

Luintel, H. and Timsina, N. 2008. How Effective is the Community Forestry in Recognizing Women as Empowered Agencies? A Research Report. Kathmandu: ForestAction Nepal.

Luintel, H., Banjade, M.R., Neupane, H.R. and Pandey, R.K. 2004. Issues of Sustainable Non-Timber Forest Product Management and Ways Forward. In: K.R. Kanel, P. Mathema, B.R. Kandel, D.R. Niraula, A.R. Sharma and M. Gautam (Eds.), Twenty Five Years of Community Forestry: Proceedings of the Fourth National Community Forestry Workshop (pp 42-47). Kathmandu: Community Forestry Division, Department of Forest.
Luintel, H., Ojha, H., Rana, B., Subedi, R. and Dhungana, H. 2009. Community Forestry in Nepal: Promoting Livelihoods, Community development and the Environment. ForestAction Nepal and Livelihoods and Forestry Programme.

Luintel, H. 2006. Do Civil Society Organizations Promote Equity in Community Forestry? A Reflection from Nepal's Experiences. In S. Mahanth, J. Fox, M. Nurse and L. Mclees (Eds.). Hanging o the Balance: Equity in Community-Based Natural Resource Management in Asia (pp 122-142). Bangkok: East-West Centre and RECOFTC.

Malla, Y.B., Neupane, H.R. and Branney, P.J. 2003. Why Aren't Poor People Benefiting More from Community Forestry? Journal of Forest and Livelihood, 3(1): 78-90.

MoEST. 2004. Initial National Communication Report on Climate Change. Kathmandu: Ministry of Environment, Science and Technology, Government of Nepal.

Neupane, H. 2003. Contested Impact of Community Forestry on Equity: Some Evidence from Nepal. Journal of Forest and Livelihood, 2(2): 55-62.

Oli, B.N. and Shrestha, K. 2009. Carbon Status in Forests of Nepal: An Overview. Journal of Forest and Livelihood, 8(1): 63-66.

Paudel, N.S., Luintel, H., Khatri, D. and Bhandari, K. 2012. Enabling Forest Users to Exercise Their Rights: Rethinking Regulatory Barriers to Communities and Smallholders Earning Their Living from Timber. A Study Report. ForestAction Nepal and RECOFTC.

Paudel, N.S., Ojha, H. and Rana, S. 2010. Capacity Building Needs Assessment and Training Strategies for Grassroots REDD Stakeholders in Nepal. A Study Report. ForestAction Nepal and RECOFTC.

Pellow, D.N. and Brulle, R.J. 2005. Power, Justice, and the Environment: Toward Critical Environmental Justice Studies. MIT Press.

Pettenella, D. and Brotto, L. 2012. Governance Features for Successful REDD+ Projects Organization. Forest Policy and Economics, 18: 46-52.

Phelps, J., Webb, E. and Agrawal, A. 2010. Does REDD Threaten to Recentralize Forest Governance? Science, 328: 312-313.

Pokahrel, B. 2005. Community Forest User Group: Institution to Protect Democracy and Vehicles for Local Development. Journal of Forest and Livelihood, 4(2).

Pokharel, B.K., Branney, P., Nurse, M. and Malla, Y.B. 2007. Community Forestry: Conserving Forests, Sustaining 
Livelihoods and Strengthening Democracy. Journal of Forest and Livelihood, 6(2): 8-19.

Ratsimbazafy, L.C., Harada, K. and Yamamura, M. 2011. Forest Conservation and Livelihood Conflict in REDD: A Case Study from the Corridor Ankeniheny Zahamena REDD Project, Madagaskar. International Journal of Biodiversity and Conservation, 3(12): 618-630.

Toni, F. 2011. Decentralization and REDD+ in Brazil. Forests, 2: 66-85.
Wollenberg, E. and Springate-Baginski, O. (Eds). 2010 REDD, Forest Governance and Rural Livelihoods: The Emerging Agenda. CIFOR, Bogor, Indonesia.

Yadav, N.P., Dev, O.P., Springate-Baginski, O. and Soussan, J. 2003. Forest Management and Utilization under Community Forestry. Journal of Forest and Livelihood, 3(1): $37-50$ 